\title{
Fossil palm woods of Egypt. I- Palmoxylon aschersoni Schenk and P. libycum (Stenzel) Kräusel
}

\author{
Wagieh El- Saadawi, \\ Botany Department, Faculty of Science, \\ Ain Shams University, Cairo, Egypt. \\ E-mail: elsaadawy@link.com.eg \\ Said, G. M. Youssef, \\ Botany Department, Faculty of Science, \\ Zagazig University, Egypt, \\ E-mail: saidyoussef58@maktoob.com \\ and \\ Marwah, M. Kamal El-Din \\ Botany Department, Faculty of Science, \\ Ain Shams University, Cairo, Egypt. \\ E-mail: awwa_kamal@hotmail.com
}

El- Saadawi, W., Youssef, S. G. M. \& Kamal El-Din, M. M. Fossil palm woods of Egypt. I- Palmoxylon aschersoni Schenk and P. libycum (Stenzel) Kräusel. Taeckholmia 22(2):143-153.

Palmoxylon aschersoni and $P$. libycum, were described, based on investigation of specimens collected from new sites in Egypt, these were compared with earlier finds and differences noted. Distribution of the two species in Africa and their affinities are given.

Key words: Palmoxylon aschersoni, P. libycum, Tertiary, Egypt.

\section{Introduction}

There are about 130 Palmoxylon species reported worldwide: Asia, Europe, Africa and the New World, of which only five species have been reported, up till now, from Egypt. The five species are:

i- Palmoxylon aschersoni Schenk: from Tertiary of the Eastern Desert, Western Destert and

Sinai (Stenzel, 1904; Kräusel \& Stromer, 1924; Kräusel, 1939; Kaul, 1960; Louvet, 1973;

Boureau et al., 1983; Youssef, 1993; Dupéron-Laudoueneix \& Dupéron, 1995). Reference

had been made to two varieties of $P$. aschersoni: var. verum and var. schweinfurthi (see

Stenzel, 1904; Kaul, 1960; Dupéron-Laudoueneix \& Dupéron, 1995).

ii- P. lacunosum (Unger) Felix: from Tertiary of the Western Desert (Kräusel \& Stromer, 1924; Kräusel, 1939; Kaul, 1960; Dupèron-Laudoueneix \& Dupéron, 1995).

iii- P. libycum (Stenzel) Kräusel: from Tertiary of the Eastern Desert, Western Desert and Sinai (Stenzel, 1904; Kräusel \& Stromer, 1924; Kräusel, 1939; Youssef, 1993; DupéronLaudoueneix \& Dupéron, 1995).

Received 9 October, 2002. Revision accepted 15 October, 2002. 
iv- $P$. stromeri (Kräusel) Kräusel (=P. lacunosum var. stromeri Kräusel): from Late Cretaceous of the Eastern Desert (Stenzel, 1904; Kräusel \& Stromer, 1924; Kräusel, 1939; Kaul, 1960; Dupéron-Laudoueneix \& Dupéron, 1995).

v- P. zitteli Schenk: from Late Cretaceous of the Western Desert (Stenzel, 1904; Kräusel \& Stromer, 1924; Kräusel, 1939; Kaul, 1960; Dupéron-Laudoueneix \& Dupéron, 1995).

Palmoxylon stromeri and $P$. zitteli are of Cretaceous age and come from the southern part of Egypt, while Palmoxylon aschersoni, $P$. lacunosum and $P$. libycum are of younger age and come from the northern parts of the country. In general the age of Palmoxylon in Egypt extends from Late Cretaceous (Senonian) to Late Tertiary (Pliocene) and its remains come mainly from sites in the Western Desert (Fig. 1). There is however, a much earlier report on the occurrence of a specimen of palm trunk in Aswan area (Upper Egypt) by Roziére (181324), but without reference to any particular taxon.

Other palm remains reported from Egypt include four fruits (cf. Coryphoicarpus globoides Koch., Hyphaeneocarpon aegyptiacum Vaudois-Miéja \& Lejal-Nicol, Nipa burtini (Brongniart) Ettingshausen and Palmacites rimosus Heer); one leaf (Sabalites sp.) and one sheathing leaf base (Palmocaulon). These remains are of similar age to the stems of MiddleLate Cretaceous to Miocene reported by Heer, 1876; Bonnet, 1904; Kräusel \& Stromer, 1924; Fritel, 1926; Kräusel, 1939; Chandler, 1954; Kaul, 1960; Gregor \& Hagn, 1982; Boureau et al. 1983; Vaudois-Miéja \& Lejal-Nicol, 1987; Kamal El-Din, 1999). In addition to these remains a Miocene structure referred to Hyphaene thebaica (L.) C. Martius was reported by Fourtau (1918), a Pleistocene leaf of ? Phoenix sylvestris Rosch by Gardner (1935) and Oligocene fanshaped leaves of palms by Wing \& Tiffney (1982).

The aim of this paper is to describe specimens of Palmoxylon aschersoni and $P$. libycum collected from new as well as old sites in Egypt and to compare them with earlier descriptions.

\section{Materials and Methods}

Fifty-two (48 well-preserved and 4 ill-preserved) specimens of fossil palms were collected between the years 1995-1997 from seven sites (Qaret EL-Raml, Gebel Ruzza, Tall EL-Zalat, Gebel Qatrani, Gebel El-Khashab (Southern Petrified Forest), Qattamiya, and Wadi Natrun, Fig. 1)

The first five sites are new (no palms reported earlier from them) while the other two sites are old (cf. Stenzel, 1904; Kräusel \& Stromer, 1924; Kräusel, 1939). The specimens were taken from small or large trunk fragments reaching $3 \mathrm{~m}$ in length and $0.5 \mathrm{~m}$ in diameter (see Fig. 3).

Ground thin sections (T.S. \& L.S.) were prepared from all collected specimens (cf. Lacey, 1963). The specimens and slides are deposited in the palaeobotanical collection of the Department of Botany, University of Ain Shams, Cairo, Egypt.

A large number of microphotographs have been taken to show fine details of cross and longitudinal sections prepared form the collected specimens using a light microscope, Minolta XEII camera and Kodak films. 


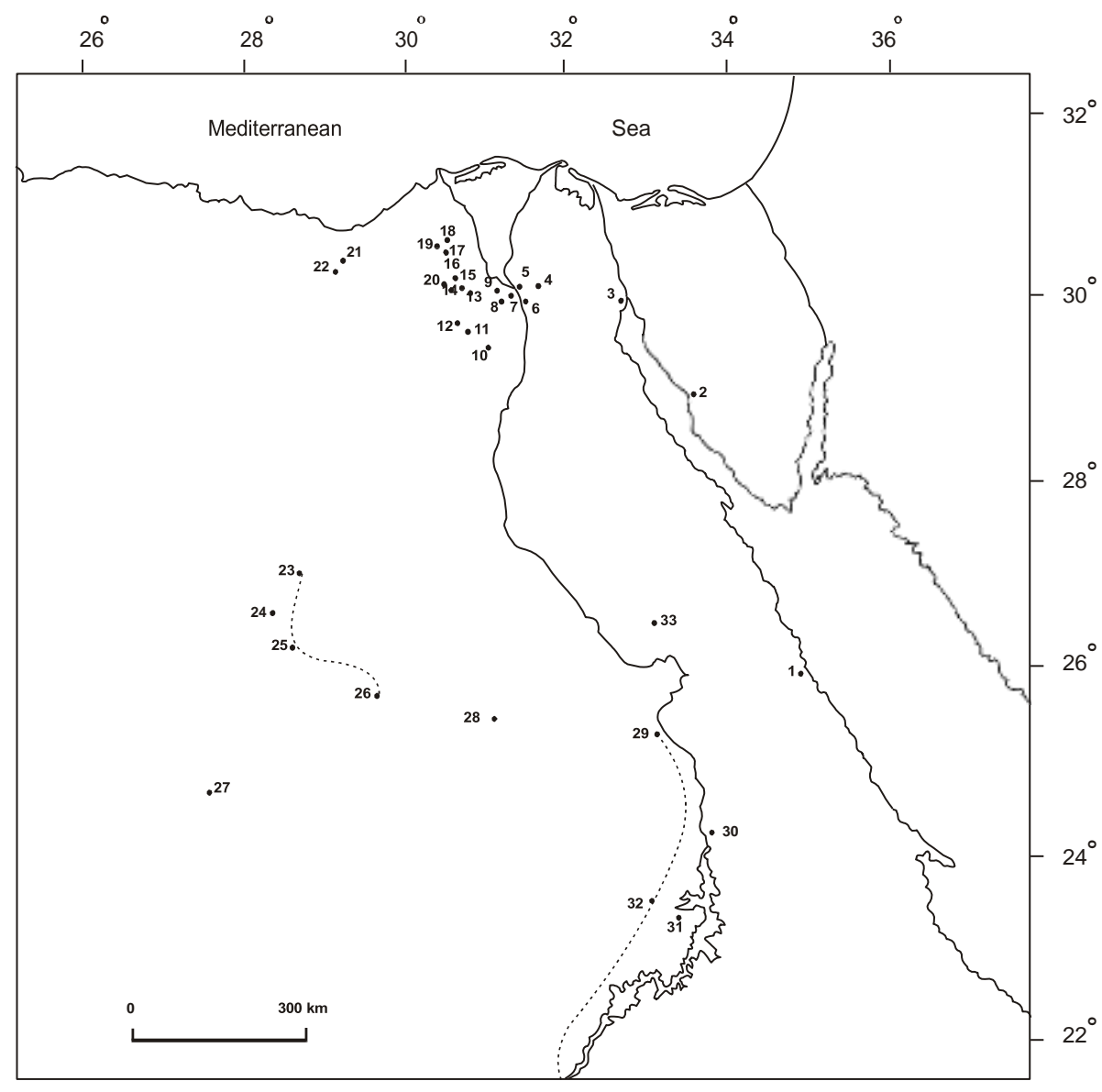

Fig. 1. Map showing sites from which fossil palm remains (leaves, fruits \& stems) were recorded in Egypt. Names of the five new sites of collection are bold typed below.

1-Quseir, 2- Gebel Hadahid and Gebel El-Bahr in Sinai, 3- Suez, 4- Qattamiya, 5- Gebel Ahmer, 6Gebel Giuschi and Gebel Mokattam, 7- Giza Pyramids and Abu Roasch, 8-Gebel El-Khashab ( Northern Petrified Forest \& Southern Petrified Forest), 9 -Tall El-Zalat, 10- Faiyum, 11- Birket Qarun, 12- Gebel Qatrani, 13- Qaret El-Raml, 14- Gebel Ruzza, 15- Wadi Faregh, 16- Deir Abu Makâr, 17- Garet El-Muluk, 18- Wadi Natrun, 19- Deir Baramûs, 20- Garet Aujân, 21- Bir Lebuk, 22- Moghra, 23- Farafra, 24- Abu Munqar, 25- Road between Farafra and Dakhla, 26- Dakhla, 27Regenfeld, 28- Kharga, 29- Esna, 30- Aswan, 31- Lake Nasser Abu Simbel, 32- Road between Esna and Wadi Halfa, 33- Wadi Hammamat. 


\section{Identification}

Careful study of the anatomy of the 48 well-preserved Palmoxylon specimens and following Stenzel's 1904 scheme of classification (see Fig. 2); the 48 specimens proved to belong to 13 distinct species. Ten specimens belonged to Palmoxylon aschersoni and four specimens to $P$. libycum; both are old records while the remaining 34 specimens were not described earlier from Egypt and will be the subject of forthcoming publications.

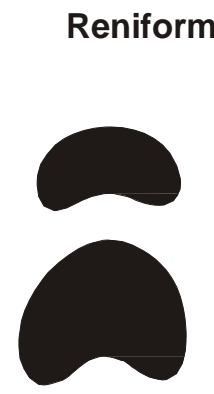

Lunate

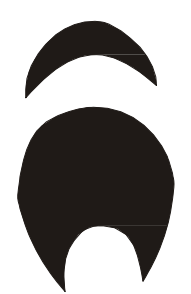

Cordate

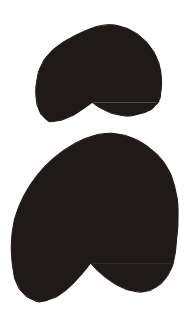

Complanate
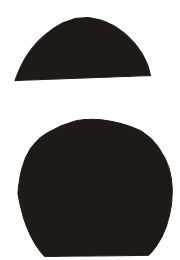

\section{Sagittate}

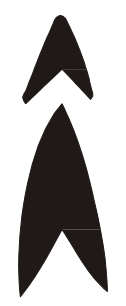

Vaginate

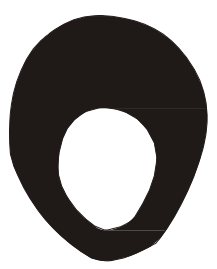

Fig. 2. Different forms of sclerenchyma in palm stems, according to Stenzel's classification scheme (after Sahni, 1964).

Palmoxylon aschersoni and P. libycum belong to groups Lunaria and Reniformia respectively (Fig. 2). In this aspect, we have to indicate the number of specimens collected from each site.

Palmoxylon aschersoni: Qaret EL-Raml (Early Miocene, specimens Nos. 129, 130, 130`, 132, 139), Gebel Ruzza (Early Miocene, specimen No. 21), Wadi Natrun (Miocene, specimens Nos. 1, 3, 4, 11). P.libycum : Wadi Natrun (Miocene, specimens Nos. 5, 12), Gebel El-Khashab Southern Petrified Forest (Early Miocene, specimens Nos. 3, 4). 


\section{Description}

\section{Group: Lunaria Stenzel \\ Palmoxylon aschersoni Schenk, (Figs. 4-7) \\ Parts available: Subdermal zone.}

Fibrovascular bundles mainly regular in distribution, average size $1.3 \times 0.9 \mathrm{~mm}$, average frequency 26-35 per $\mathrm{cm}^{2}$, f/v ratio (the ratio between areas occupied by the sclerenchyma and the vascular part as seen in cross section) 2/1 (Fig. 4).

Sclerenchyma lunate (Fig. 5), orbicular, rarely more or less renifrom (Fig. 6), auricular lobes angular (Fig. 5), rarely \pm rounded (Fig. 6), median sinus rounded (Figs. 5, 6). Fibrous bundles absent. Diminutive fibrovascular bundles present. Xylem one large vessel (Fig. 6) or bivasal (Fig. 5). Phloem ill-preserved in two masses (Fig. 6). Ground tissue compact with small air spaces, tabular parenchyma 1-2 layers around the fibrovascular bundle (Fig. 6), radiate parenchyma absent. Leaf traces present.

In longitudinal section: parenchyma cells appear in contiguous vertical rows, separated by small air spaces at intervals. Perforation plates with oblique end walls (Fig. 7), intervessel pits alternate (Fig.7).

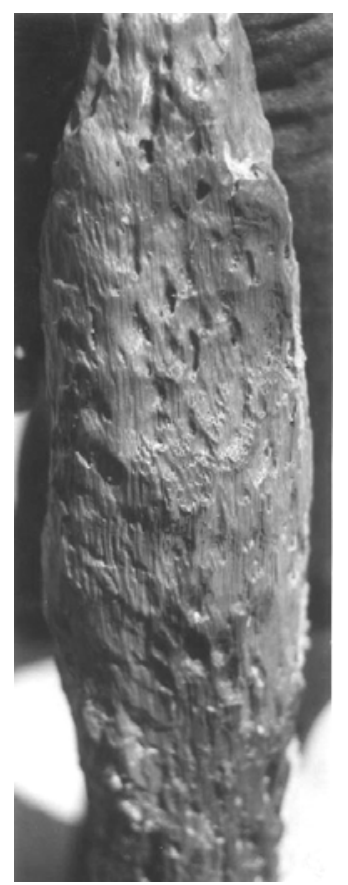

Fig. 3. A palm trunk at Gebel El-Khashab, $x 0.2$ one of the sites of collection.

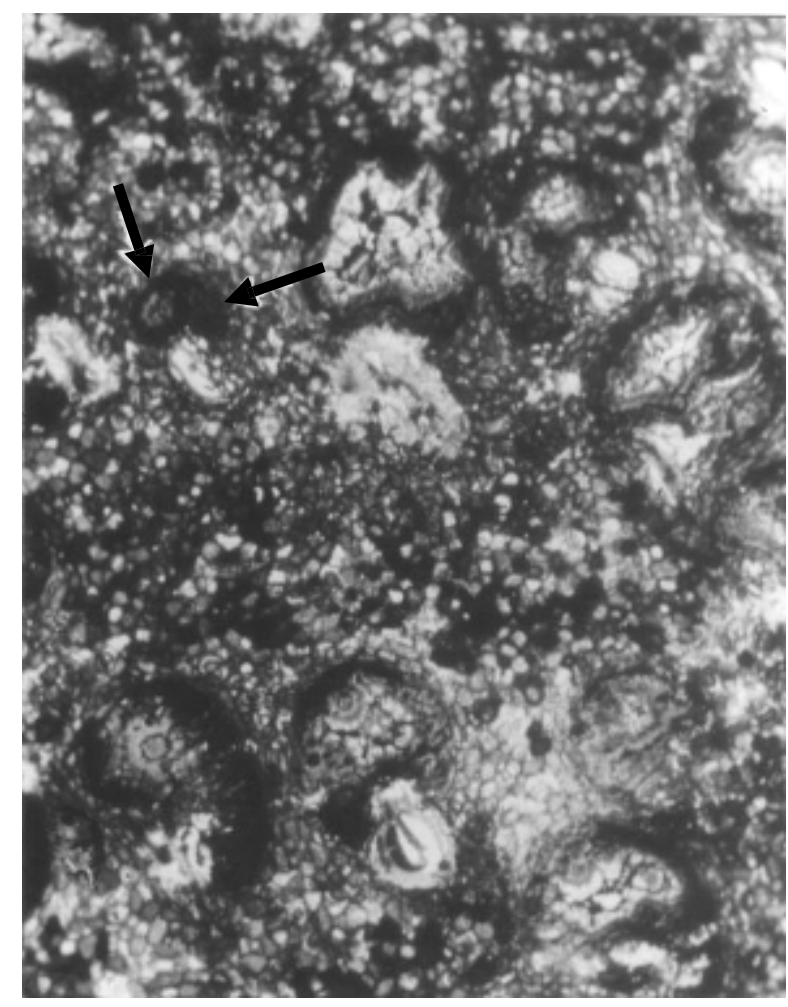

Fig. 4. Palmoxylon aschersoni, cross section showing distribution of fibrovascular bundles, and diminutive fibrovascular bundle (arrows),x 15. 


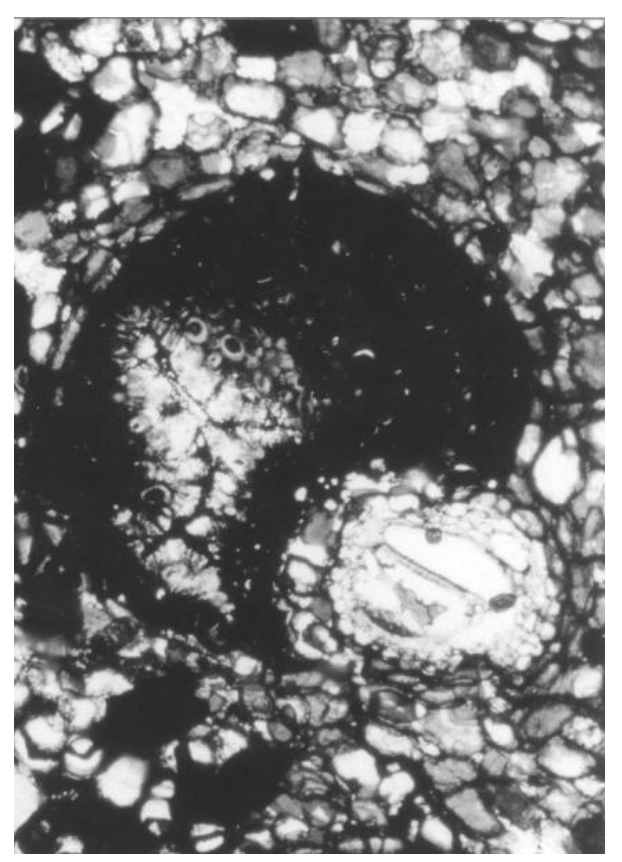

Fig. 5. Palmoxylon aschersoni, part of a cross section magnified to show lunate shaped sclerenchyma, auricular lobes, median sinus, and xylem vessels, x70.

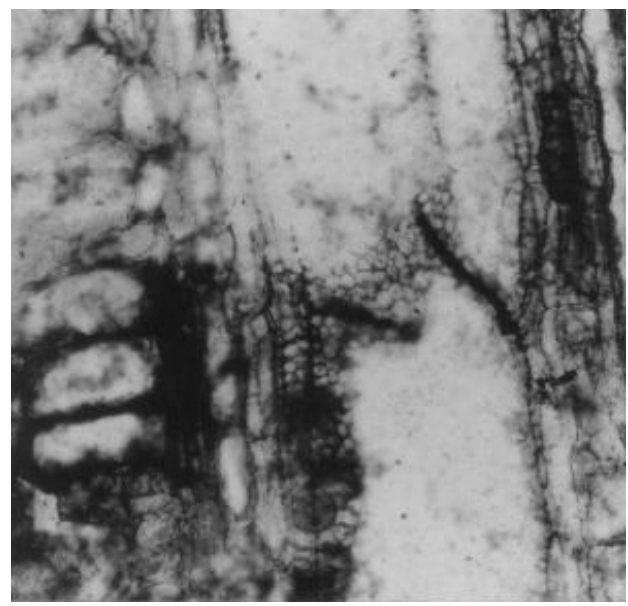

Fig. 7. Palmoxylon aschersoni, part of a longitudinal section magnified to show alternate intervessel pits and oblique end walls, x130.

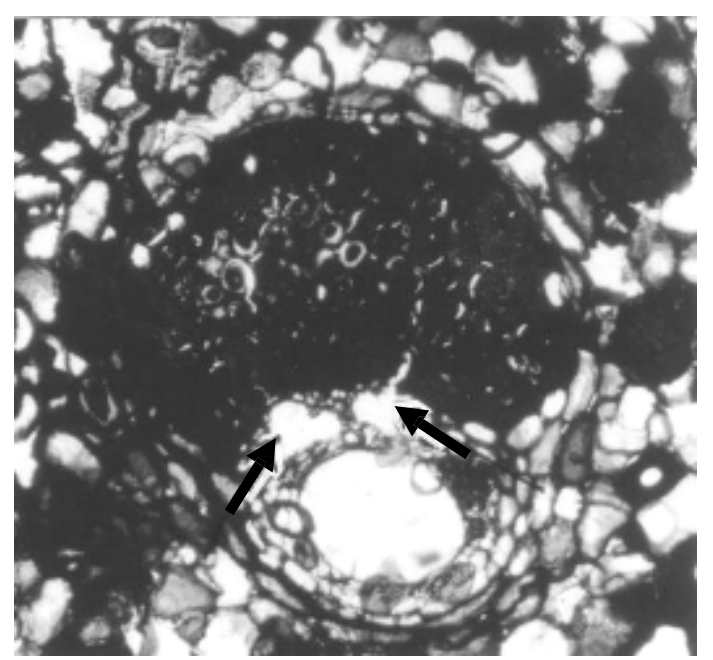

Fig. 6. Palmoxylon aschersoni, part of a cross section magnified to show xylem vessels, phloem masses (arrows), and tabular parenchyma around the whole bundle, $x 70$.

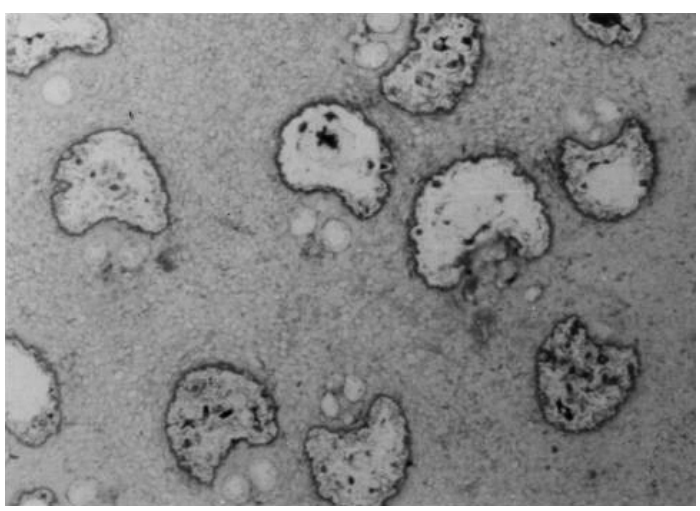

Fig. 8. Palmoxylon libycum, cross section showing irregular distribution of fibrovascular bundles, and reniform sclerenchyma, x20. 
Fossil palm woods of Egypt. I- Palmoxylon aschersoni Schenk and P. libycum (Stenzel) Kräusel

\section{Group: Reniformia Stenzel}

Palmoxylon libycum (Stenzel) Kräusel, (Figs. 8-10)

Syn. P. cottae Unger var. Libycum Stenzel.

Parts available: Central zone

Fibrovascular bundles irregular in distribution, average size $1.4 \times 1 \mathrm{~mm}$, average frequency 2941 per $\mathrm{cm}^{2}$, f/v ratio 1.5-2/1 (Fig. 8). Sclerenchyma reniform (Fig. 8), auricular lobes rounded (Fig. 8), median sinus rounded and shallow (Fig. 8). Fibrous bundles absent. Diminutive fibrovascular bundles absent. Xylem two rounded vessels 0.26 x $0.36 \mathrm{~mm}$ (Fig. 9). Phloem illpreserved in 1-2 masses. Ground tissue compact, cells thin-walled and small, tabular parenchyma 1-2 layers over sclerenchyma (Fig. 9), radiate parenchyma absent. Leaf traces absent.

In longitudinal section: parenchyma cells appear in contiguous vertical rows (Fig. 10). Perforation plates simple, intervessel pits alternate and spiral (Fig. 10).

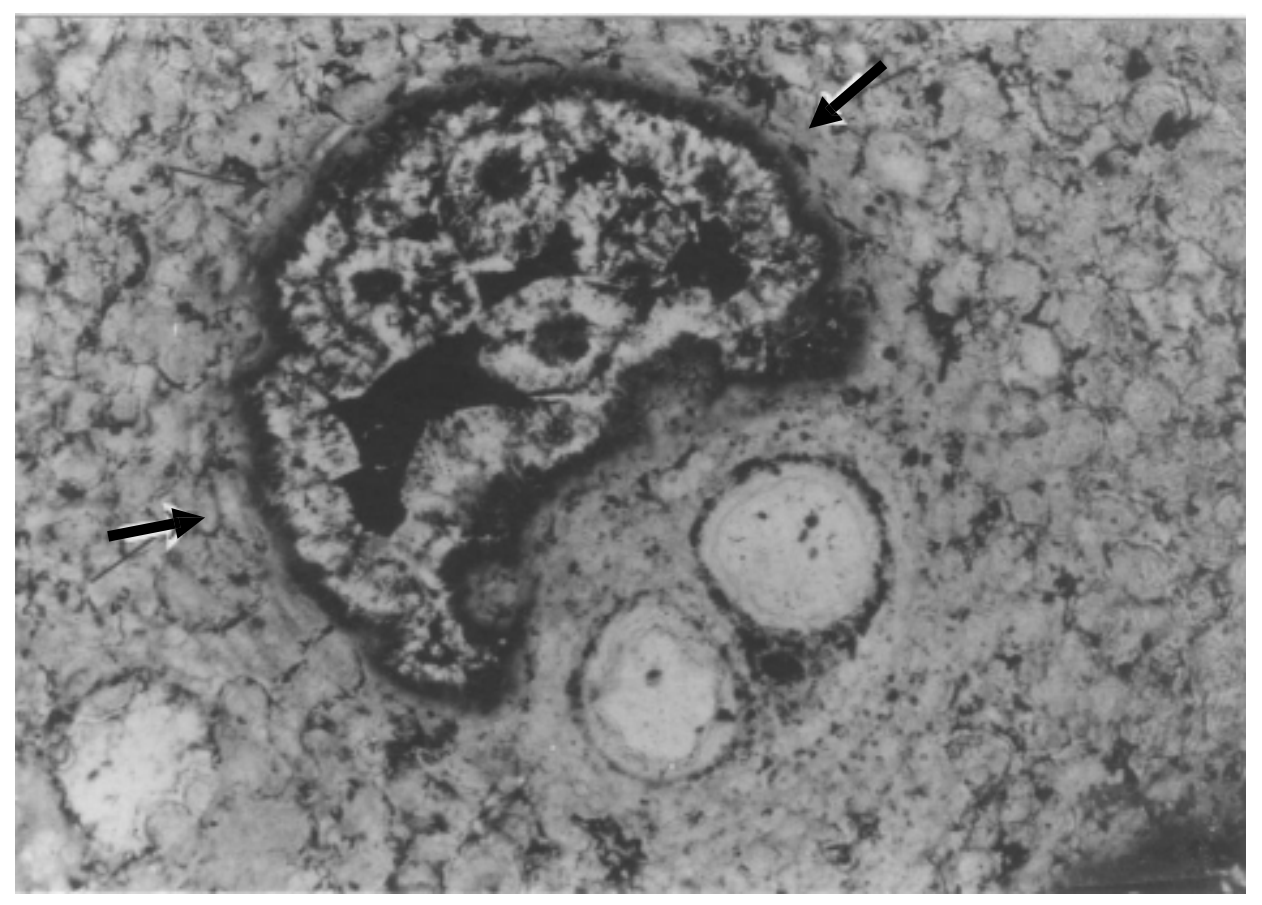

Fig. 9. Palmoxylon libycum, part of a cross section magnified to show reniform sclerenchyma, auricular lobes, median sinus, xylem vessels, ground tissue, and tabular parenchyma (arrows), x70. 


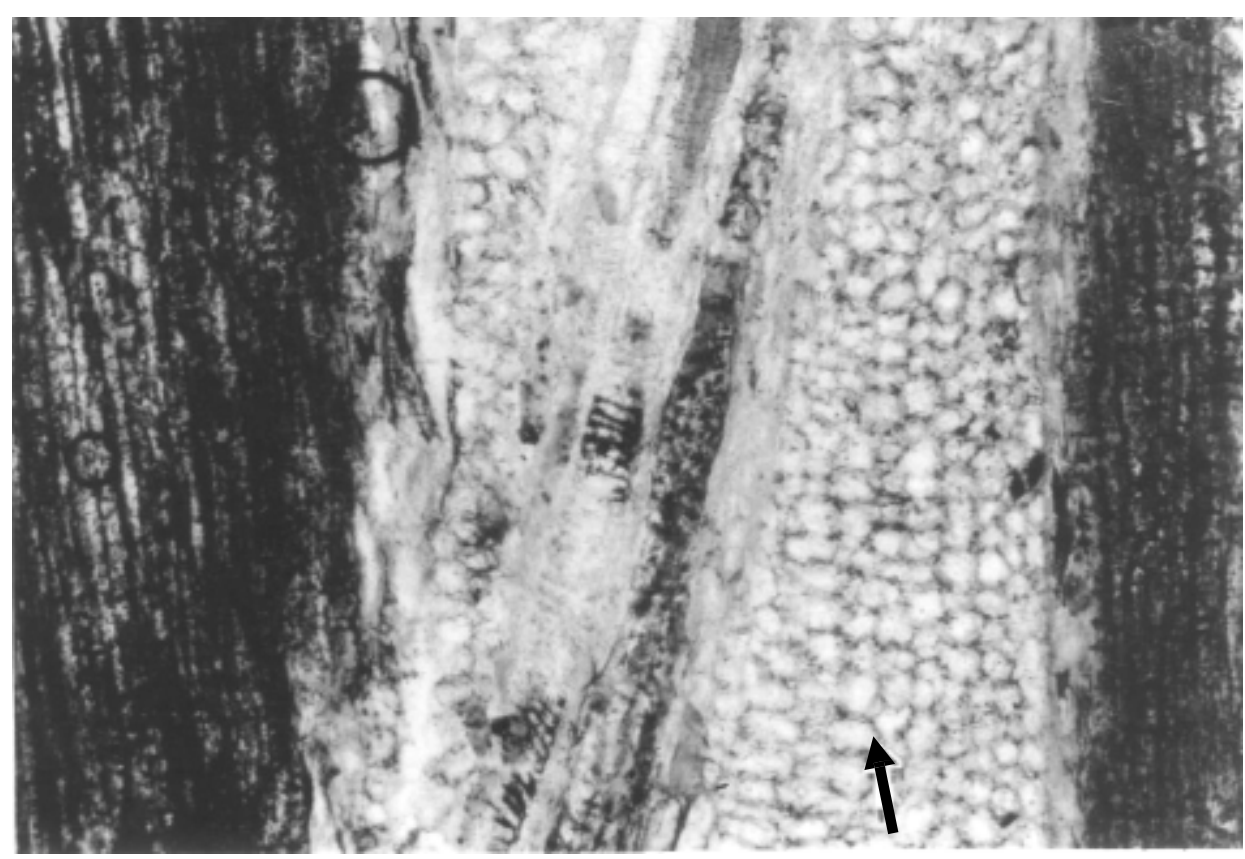

Fig. 10. Palmoxylon libycum, longitudinal section showing compact parenchyma cells (arrow) and other anatomical features, x65.

\section{Comparisons and Affinities}

There are some slight differences in the description of $P$. aschersoni and $P$. libycum as given by Kräusel and Stromer (1924) and as observed in present work (Table 1).

Table 1. Wood features of Palmoxylon aschersoni and P. libycum as given by Kräusel \& Stromer (1924) and as observed in present work.

\begin{tabular}{|l|c|c|}
\hline \multirow{2}{*}{ Features } & \multicolumn{2}{c|}{ P. aschersoni } \\
\cline { 2 - 3 } & Kräusel \& Stromer, (1924) & Present work \\
\hline \multirow{2}{*}{ Parts available } & Not mentioned & Subdermal zone \\
\hline Average size of bundles & $2 \times 0.75 \mathrm{~mm}$ & $1.3 \times 0.9 \mathrm{~mm}$ \\
\hline Average frequency of bundles & $23-38$ per cm ${ }^{2}$ & $26-35$ per $\mathrm{cm}^{2}$ \\
\hline \multicolumn{2}{|c|}{ P. libycum } \\
\hline Parts available & Not mentioned & Central zone \\
\hline Average size of bundles & $1.5 \times 0.8 \mathrm{~mm}$ & $1.4 \times 1 \mathrm{~mm}$ \\
\hline Average frequency of bundles & $22-40$ per cm ${ }^{2}$ & $29-41$ per cm ${ }^{2}$ \\
\hline
\end{tabular}


Fossil palm woods of Egypt. I- Palmoxylon aschersoni Schenk and P. libycum (Stenzel) Kräusel

The present results indicate that $P$. aschersoni (10 specimens) was not only more common in Egypt than P. libycum (4 specimens) but as reported also by Kräusel \& Stromer (1924) and Youssef (1993) it was more widespread; being reported from 15 sites (Gebel Hadahid-Gebel El-Bahr, Suez, Qattamiya, Giza Pyramids, Abu Roasch, Gebel El-Khashab (Northern Petrified Forest), Fayum, Qaret El-Raml, Gebel Ruzza, Garet El-Muluk, Wadi Faregh, Wadi Natrun, Garet Aujân, Bir Lebuk, Moghra) compared to eight sites (Gebel Hadahid-Gebel El-Bahr, Qattamiya, Gebel El-Khashab (Southern Petrified Forest), Giza Pyramids, Birket Qarun, Wadi Faregh, Wadi Natrun, Deir Baramus) for P. libycum.

Furthermore $P$. aschersoni was more widespread in Africa being reported from the Early Miocene of Libya, Tertiary of Algeria and Tertiary of the Sudan (Chiarugi, 1929a; Louvet, 1973; Delteil-Desneux \& Koeniguer, 1974; Boureau et al. 1983; DupéronLaudoueneix \& Dupéron, 1995) while P. libycum was reported from only the Tertiary of Libya (Chiarugi, 1929b; Boureau et al. 1983; Dupéron-Laudoueneix \& Dupéron, 1995).

Many authors worked on the anatomy of the modern palms as Karsten (1847), Mohl (1849), Eichler (1886), Stenzel (1904), Strasburger (1906), Solereder \& Meyer (1928), Kaul (1960), Tomlinson (1961a, b) and others. Only Mohl (1849), classified modern palms on the basis of the stem anatomy; his artificial classification is hitherto the best available scheme of grouping palm stems (cf. Sahni, 1964). He recognized five types namely: 1- Geonoma-like (Corypha-like) forms, 2- Calamus-like forms, 3- Mauritia-like forms, 4- Coccos-like forms and 5- Stemless-palms forms.

Stenzel (1904) used Mohl`s (1849) scheme in his work on fossil palm species and accordingly the main fossil types recognized by the first are grouped only under Corypha-like and Cocos-like. Anatomical features of the two studied species in this work (Palmoxylon aschersoni of group Lunaria and P. libycum of group Reniformia) show that they are related to Cocos-like forms, extant representatives of which are widely distributed in Africa including Egypt (cf. Mabberley, 1990; Bebawi \& Neugebohrn, 1991; El-Hadidi \& Fayed, 1994/1995).

It must be mentioned that $P$. stromeri (group Vaginata) and $P$. zitteli(group Lunaria) which were reported earlier from Egypt by Kräusel \& Stromer (1924) and Kräusel (1939) belong also to Cocos-like forms (cf. Kamal El-Din, 1999) whereas P. lacunosum of group Complanta (reported earlier from Egypt by Kräusel \& Stromer, 1924 and Kräusel, 1939) belongs to the Corypha-like forms (Stenzel, 1904).

\section{Acknowledgements}

The authors wish to thank Dr. Rifaat Osman, assistant Prof. of Geology, Faculty of Science, Benha University, for his kindness and for guidance in desert excursions. Sincere thanks are also due to Prof. Dr. Samir Ghabbour for kindly providing us with some references.

\section{References}

Bebawi, F.F. \& Neugebohrn, L. 1991. A review of plants of Northern Sudan. Deutsche Gefellschaft für Technische Zusammenarbeit (GTZ) GmbH Eschborn. 1-294.

Bonnet, E. 1904. Sur un Nipadites de l'eocéne d’Égypte. Bull. Mus. d'Hist. Natur., Paris, 10: 499-502.

Boureau, E., Cheboldaeff-Salard M., Koeniguer J.C. \& Louvet P. 1983. Evolution des flores et de la végétation Tertiaires en Afrique, au nord de l'Equateur. Proc. $10^{\text {th }}$ AETFAT Congr., Pretoria, 1982. Bothalia, 14 (3/4): 355 - 367. 
Chandler, M.E.J. 1954. Some Upper Cretaceous and Eocene fruits from Egypt. Bull. Brit. Mus. (N.H), Geol. 2: 149-187.

Chiarugi, A. 1929a. Prime notizie sulle foreste pietrificate della Sirtica. N.G. Bot. Ital. n.s., 35: 558-566.

Chiarugi, A 1929b. Legni fossili. In: Resultati scientifici della Missione alla Oasi di Giarabub (1926-1927). Parte III: La Palaeontologia. R. Soc. Geogr. Ital., Romé : 397-430.

Delteil-Desneux, F. \& Koeniguer, J.C. 1974. Les bois du Tertiaire de l’Algérie. Bull. Soc. Hist. Nat. Afr. Nord, 65 (1/2): 67-80.

Dupéron-Laudoueneix, M. \& Dupéron, J. 1995. Inventory of Mesozoic and Cenozoic woods from Equatorial and North Equatorial Africa. Review of Palaeobotany and Palynology 84: 439-480.

Eichler, A.. W. 1886. Ueber die Verdichnugsweise d. Palmenstamme. Sit-zber. Kgl. Preuss. Akad. Wiss. Berlin.

El-Hadidi, M.N. \& Fayed, A.A. 1994/1995. Materials for Excursion Flora of Egypt (EFE). Täckholmia 15: 1-233.

Fourtau, R. 1918. Contribution á L’étude des Vertébrés miocénes de L’Egypte. Survey Dept., Cairo.

Fritel, P.H. 1926. Remarques additionalles sur la flore fossile du Grés de Nubie. Bull. Mus. Hist. Natur., Paris, 32: 315-319.

Gardner, E. W. 1935. The Pleistocene Fauna and Flora of Kharga Oasis, Egypt. Quart. Jour. Geol. Soc. London, 91:479-518.

Gregor, H.J. \& Hagn, H. 1982. Fossil fructifications from the Cretaceous-Paleocene boundary of SW Egypt (Danian, Bir Abu Munqar) Tert. Res. 4: 121-147.

Heer, O. 1876. Über Fossile Früchte der Oase Chargeh. Denksch. Schweiz. naturf. Ges., Bd. 27: 11 S., Zürich.

Kamal Fl-Din, M. M. 1999. Studies on petrified palms from Egypt. Ph. D. Thesis, Bot. Dept., Fac. of Science, Ain Shams Univ. Cairo, Egypt.

Karsten, H. 1847. Die Vegetationsorgane der Palmen. Ein Beitrag zur vgl. anat. und physiologie. Schriften d. kgl. Akad. d. Wiss. Berlin.

Kaul, K.N. 1960. The anatomy of the stem of palms and the problem of the artificial genus Palmoxylon Schenk. Bull. National Botanic Garden, Lucknow, India, no.51. Anatomy of plants. Palms 1:1-52.

Kräusel, R. 1939. Ergebnisse der forschungsreisen Prof. E. Stromers in den Wüsten Ägyptens. IV. Die fossilen Floren Ägyptens. 3. Die Fossilen Pflanzen Ägyptens, E-L. Abh. Bayer. Akad. Wiss., Math.-Nat.Abt. N.f., 47: 1-140.

---------- \& Stromers, E. 1924. Ergebnisse der forschungsreisen Prof. E. Stromers in den Wüsten Ägyptens. IV., Die fossilen Floren Ägyptens 1-3. A-C. Abh. Bayer. Akad. Wiss. Math.-Nat. Abt., 30(2): 1-48.

Lacey, W.S. 1963. Palaeobotany Technique, View Pionts in Biology, (Editors J.D. Carthey and I.Duddington) 2: 202-243.

Louvet, P. 1973. Sur les affinités des flores tropicales ligneuses africaines tertiaire et actuelle. Bull. Soc. Bot. France, 120(9): 385-396.

Mebberley, D.J. 1990. The Plant Book. Cambridge.

Mohl, H. Von 1849. On the structure of the palm-stem. English translation published by the Ray Society, London.

Roziére, F. 1813-1824. De la constitution physique de l'Egypte et de ses rapports avec les anciennes institutions de cette contrée. Description de l'Égypt (Histoire Naturelle), Paris. $1^{\text {st }}$ ed. 1813, 2:407-732, $2^{\text {nd }}$ ed. 1824, 20:211-523, \& 21. 1826:1-324. 
Fossil palm woods of Egypt. I- Palmoxylon aschersoni Schenk and P. libycum (Stenzel) Kräusel

Sahni, B. 1964. Revisions of Indian fossil plants. Part III- Monocotyledns. Monogr-Sahni Inst. Palaeobot., 1: 1-89.

Solereder, H. \& Meyer, F.J. 1928. Systematische Anatomie der Monokotylen. Berlin.

Stenzel, K.G. 1904. Fossile Palmenhölzer. Beit. z. Pal. u. Geol. Österr. -Ung. u. d. Orients Bd. 16: 107-287.Wien.

Strasburger, E. 1906. Uber die Verdickungsweise der stamme von Palmen und Schrauben bäumen. Leipzig.

Tomlinson, P.B. 1961a. Anatomy of Monocotyledons (ed. C. R. Metcalfe), vol. 2 Palmae. Oxford.

Tomlinson, P.B 1961b. Essays on the morphology of palms. VI. The palm stem. Principes 5 : 117-124.

Vaudois-Miéja N. \& Lejal-Nicol A. 1987. Paleocarpologie africaine: apparition dés l’Aptien d'un Palmier (Hyphaenocarpon aegyptiacum n. sp.) C.R. Acad. Sci., Paris 304, ser. II(6):233-238.

Wing, S.L. \& Tiffney, B.M. 1982. Plant fossils in: Bown, T.M., Kraus, M.J., Wing, S.L., Fleagle, J.G., Tiffney, B.H., Simons, E.L. \& Vondra, C.F. 1982. The Fayum primate Forest Revisited. Journal of Human Evolution 11:603-632.

Youssef, S. G. 1993. Studies on some Egyptian fossil woods. Ph.D. Thesis, Bot. Dept., Fac. of Sci., Benha, Zagazig Uni. Egypt. 